Article

\title{
Syrian Refugee Entrepreneurship in Turkey: Integration and the Use of Immigrant Capital in the Informal Economy
}

\author{
Reyhan Atasü-Topcuoğlu \\ Department of Social Work, Hacettepe University, 06800 Ankara, Turkey; E-Mail: ratasu@hacettepe.edu.tr
}

Submitted: 7 July 2019 | Accepted: 29 November 2019 | Published: 19 December 2019

\begin{abstract}
This study focuses on small-scale entrepreneurship of Syrian refugees in Turkey. It analyses in a Bourdieusian way how they utilize cultural, social, economic and symbolic capital, and reveals their start-up and sustainability strategies. It is based on 24 in-depth interviews with Syrian small entrepreneurs who started up new businesses after 2011, in Istanbul, Gaziantep, and Hatay. It describes the entrepreneurial opportunity structure and the significance of the informal economy and analyses Syrians' utilization of various forms of capital in small entrepreneurship and relations to integration. The main finding indicates that the informal economy-as the main site of such entrepreneurship-eases the start-up process but limits on-going business and integration.
\end{abstract}

\section{Keywords}

entrepreneurship; informal economy; integration; refugees; social capital; Syrian refugees; Turkey

\section{Issue}

This article is part of the issue "Social Inclusion beyond Borders: Utilization of Migrant Capital in Transnational and Diaspora Communities" edited by Sanna Saksela-Bergholm (University of Helsinki, Finland), Östen Wahlbeck (University of Helsinki, Finland) and Mari Toivanen (University of Helsinki, Finland).

(C) 2019 by the author; licensee Cogitatio (Lisbon, Portugal). This article is licensed under a Creative Commons Attribution 4.0 International License (CC BY).

\section{Introduction}

The article examines the small-scale refugee entrepreneurship of Syrians in three Turkish cities and its relations to integration. As of 2019, the war in Syria is in its eighth year. Syrian refugees have fled to Turkey, Lebanon, Jordan, and Iraq. The majority, 3.6 million, have been staying in Turkey with temporary protection status (General Directorate of Migration Management [DGMM], 2019). The forced migration of Syrians has challenged host countries economically and socially and their prolonged stay has caused the emergence of integration as a policy issue. Syrian asylum to neighbouring countries has been investigated mainly through socioeconomic themes such as government expenditure, unemployment rates and inflation (Bizri, 2017). The recent literature has focused on the labour market effects and humanitarian difficulties faced by Syrian immigrants in Turkey. Integration has only recently been rising on the scholarly and political agenda for Syrians in Turkey, who have long been termed 'guests.' Despite the im- portance attributed to economic aspects, such as the cost of welfare benefits (Kızılay, 2019) and crowdingout effects on the labour market (Ceritoğlu, Yunculer, Torn, \& Tumen, 2017) in debates about migration policy and integration, refugee entrepreneurship remains a rather understudied topic. This article contributes to filling this gap by combining findings from field research and knowledge of the international literature on refugee entrepreneurship underlining its importance for integration (Bizri, 2017; Kloosterman, 2010) and of case studies on Syrian entrepreneurs in Lebanon (Alexandre, Salloum, \& Alalam, 2019), Jordan (Refai, Haloub, \& Lever, 2018), the UK (Mawson \& Kasem, 2019) and Turkey (Shneikat \& Alrawadieh, 2019). This inquiry into the Turkish case also contributes to the literature by pointing out the effects of the informal economy to debates about refugee entrepreneurship and integration.

This study focuses on the utilization of forms of capital (understood in a Bourdieusian sense) in the case of Syrian small entrepreneurs in Turkey and aims to explore the relations between these entrepreneurs in two spe- 
cific realms of integration: relations with the state and with the market. It is based on 24 in-depth interviews with Syrian entrepreneurs who established businesses after 2011, and three interviews with representatives from the Chambers of Commerce in Istanbul (the most significant metropolis in Turkey), Gaziantep (one of the fastestgrowing local economies in South-eastern Turkey since 2011), and in Hatay (a small city bordering Syria).

\section{Analytical Framework}

Studies on Syrian refugee entrepreneurship follow the mainstream line in the pertinent literature and concentrate on personality factors (Obschonka \& Hahn, 2018), personal motivations (Mawson \& Kasem, 2019; Shneikat \& Alrawadieh, 2019), and personal strategies (Bizri, 2017), also underlining legal and financial barriers. Kloosterman (2010) criticizes the mainstream literature's individualistic view and suggests concentrating on the interaction between the individual entrepreneur and his or her legal, social and economic environmentin other words, the opportunity structure. Founding a start-up requires money, know-how, relations with customers and partners, and a suitable locality to combine it all. Bourdieu's $(1986,2013)$ concept of forms of capital provides a robust basis for analysing interactions between entrepreneurs and their social environment. According to Bourdieu (1986), capital is accumulated labour-human energy spent in time, reified and accumulated as wealth, knowledge, social networks, institutions and prestige. In a topological understanding of society, diverse forms of capital are dimensions that define the place of every agent and his or her possibilities of action. The historical totality of accumulated forms of capital embodied as agency and social institutions constructs the 'field.'

Temporality and locality are necessary for such accumulation. Concerning international migration, the individual moves out of one field-namely, the original location-and enters a new one. The new field brings about changes in meaning and power-that is, in the possibilities of action provided by all forms of capital individually embodied in the agent. Moreover, when migration is irregular, as in the case of asylum seekers, the new set of relations in the typically undocumented field of the host country often shrinks these possibilities of action, bringing about uncertainty, precariousness, and ambiguity. Hence, the degree to which the opportunity structure can be leveraged or utilized differs from immigrant to immigrant.

Bourdieu's $(1986,2013)$ forms of capital offers a helpful framework to uncover group- and case-specific differences in how the opportunity structure is navigated. The analytical framework of forms of capital can be adapted in the case of Syrian entrepreneurs as follows. Their economic capital consists of money and things directly convertible to money. Their social capital includes connections that introduce new possibilities of access to resources, consisting of strong ties (e.g., family) and weaker ties (e.g., friends and fellow countrymen). The third form is cultural capital, which for Syrians incorporates a range of dimensions, including institutionalized forms such as educational certificates and diplomas, and embodied forms like tastes, skills and dispositions (like entrepreneurial flair or experience). Crucially, this embodied form of cultural capital includes occupational skills, such as cooking or hairdressing, as well as communication skills, and know-how in the manufacturing of certain goods, such as shoemaking or machine moulding. It also covers aesthetic knowledge about the preferences of target groups, local citizens, or Syrians in Turkey and verbal skills such as knowledge of Arabic, Turkish, English, etc. Finally, a component of cultural capital is expertise in local knowledge-which is to say: formal knowledge about the laws and bureaucracy necessary for starting an enterprise in Turkey, and practical knowledge of agents in the local markets, retailers, wholesalers, etc. Symbolic capital (Bourdieu, 2013) reflects the recognition and legitimation of the various other forms. It is good reputation, prestige, and respect that empowers access to networks and relations of recognition, opening possibilities to convert one type of capital to another. In this study, symbolic capital consists of prestige acquired in Syria and earned among the local community in Turkey. The significance of social capital in refugee entrepreneurship, as well as the difficulties arising from limited economic and cultural capital, are underlined in the literature (Katila \& Wahlbeck, 2012; Wahlbeck, 2007).

In sum, forms of capital constitute an analytical framework to deepen our understanding of refugee entrepreneurs' possibilities of action. However, these possibilities are affected by the legal-political and social, linguistic and economic opportunities obtaining in the host country. The opportunity structure for Syrian entrepreneurs consists, as Kloosterman (2010) suggests, in the institutional framework at the macro-level, meaning the relevant legal and policy framework regulating investment and the rights of immigrants, the mesolevel of time- or space-specific opportunities in the local economy, and the micro-level of the entrepreneur's resources. Immigrant entrepreneurship is thus agentdriven integration-namely, a proactive practice of revalidating and re-accumulating forms of capital and reclaiming and re-acquiring one's place in a new society.

The migrant entrepreneur-in leveraging the available opportunities and forms of capital-generates not only a new business enterprise but also new goods, relations, appearances, places for coming together, and intercultural communication between host and immigrant populations. Hence their experiences are interrelated with integration. In this study, analysis of Syrian small entrepreneurship focuses on integration in terms of relations with the state and the market, which are interrelated and interactive processes driven by macro- and meso-level structures as rules set by the state and market conditions, as well as micro-strategies-i.e., individ- 
ual utilization of forms of capital. The following subsections provide an overview of factors, and how they all interact in the various realms of integration.

\section{Setting the Context of Integration for Syrians in Turkey: Legal-Political and Economic Conditions as Macro- and Meso-Level Structures}

This section provides information about the number of Syrians in Turkey and the three cities pertinent to the study, the relevant legal-political framework (i.e., the principal rules institutionally set in the realm of relations with the state), and details on the local market (i.e., the context of market relations and Syrians' mesolevel opportunities).

From 2011, when the armed conflict in Syria began, through to March 2016, the Turkish government followed an open-door policy for those fleeing the conflict, accepting them as 'guests.' The refugee camps were soon overwhelmed by the sheer number of arrivals and Syrians began to settle throughout the country. By $2018,94.2 \%$ of the 3.6 million Syrian refugees were living in urban areas, with only $5.8 \%$ remaining in camps (DGMM, 2019). The Law on Foreigners and International Protection granting Syrians temporary protection status provided the legal grounds for the Turkish government's 'guest' policy, and underscored the fact that settlement was expected to be temporary and the provisions of recognition of Syrians' stay arbitrary rather than rightsbased. The formal registration of Syrians started only in 2013. Accession to the labour market was regulated in 2016 with the By-Law on Work Permits of Foreigners Under Temporary Protection, declaring that all immigrants except for those working in seasonal agriculture and stock farming would require a work permit. These are restricted according to residential areas and job sectors and are decided after evaluation of the work permit applications submitted by employers or workers. Baban, Ilcan, and Rygiel (2017) criticize the legal framework forcing unpredictability and insecurity on Syrian refugees' lives and status. This article underlines the importance of macro-economic structure and informal economy in addition to the legal structure.

The four-year delay between the beginning of the open-door policy and the regulation of work permits opened a temporal phase in which informal jobs and business could grow. Turkey has an extensive informal economy which is the main site of employment for Syrians and for some Turkish nationals as well. The informal economy was estimated at $30 \%$ to $35 \%$ of Turkish GDP between 2010 and 2015 (Elgin \& Sezgin, 2017). As the $\operatorname{OECD}(2008$, p. 88 ) has noted: "Over $40 \%$ of the [Turkish] workforce is either working in informal salaried jobs or as own-account or unpaid family workers." Today, between 750,000 and 950,000 Syrians are working informally in Turkey, according to estimates (ICG, 2018).

Turkey's existing stock of unemployment made the open-door policy a challenge in terms of labour market effects. As of 2019, Turkey's unemployment rate is $14.1 \%$ (4.5 million people; TÜiK, 2019), and the workforce potential of Syrian immigrants is 2,099,132 (DGMM, 2019). Between 2011 and 2017, 20,966 temporary work permits were issued to Syrians in Turkey (Ministry of Family, Labour and Social Services, 2019). Most of the jobs available are low-skilled, short-term, flexible and low-paid (Lordoğlu \& Aslan, 2016). Syrians work with daily wages of 5.6 TL in Hatay, monthly salaries of 406 TL in Gaziantep, and 1,000 TL Turkey-wide as of 2015 (Kutlu, 2019). Wages differ according to gender and ethnicity. In 2015, in the largest employment sector in Istanbul-namely, clothing and textiles-Turkish male and female workers earned 1,494 TL and 1,221 TL, respectively, while Syrian male and female workers earned 1,155 TL and $776 \mathrm{TL}$, respectively; the minimum wage was $1,273 \mathrm{TL}$, which is below the estimated 'hunger line' of 1,385 TL and the poverty line of 4,512 TL (Mutlu et al., 2018). The conversion at that time was approximately $2.9 \mathrm{TL}$ for every US\$1. A 2018 survey shows that Syrian workers typically earn 400 TL less than Turkish workers, who earn 1,880 TL on average (Uysal, Gursel, Anil, Uncu, \& Bakis, 2018 , p. 7). The general market conditions also affect immigrants' possibilities. For instance, Özar (2016) underlines that the small entrepreneurs are concentrated in urban areas, the bureaucracy negatively affects start-ups, and hence there is a tendency to slip into the informal market. Moreover, she notes that the male-dominated structure of the society is a severe barrier to women's entrepreneurship.

Given macro-level legal-political framework and complex labour market conditions, small business and selfemployment becomes a survival strategy and plays a role in reducing unemployment among immigrants while also benefitting the host economy (see, e.g., Carree, Congregado, Golpe, \& van Stel, 2015). As mentioned, the Turkish case is important, given its salience in shedding light on the effects of informality on immigrant entrepreneurship. In Turkey, the informal economy appears to have become the core site of economic integration for most and founding a start-up has become an attractivealbeit hard to achieve-option for Syrians with little capital, regardless whether they are registered or not.

Official statistics show the acceleration in the growth of firms with Syrian capital starting from 2010. Between 2010 and 2012, 238 new firms with Syrian capital were established, increasing to 6,311 between 2013 and 2017 (Güven, Kenanoğlu, Kadkoy, \& Kurt, 2018). According to the Building Markets report, over 7,200 companies had been formally established by Syrians in Turkey by the end of May 2018. Most of the big firms are in Istanbul. The number of firms with Syrian capital registered at the Istanbul Chamber of Commerce grew from 95 in 2012 to 3,129 in 2018 , with $10 \%$ having more than $500,000 \mathrm{TL}$ $(\$ 94,470)$ in start-up capital. Unregistered small and medium enterprises (SMEs) are estimated to be three times this number (Palacıoğlu, 2019). Building Markets (2018) estimates that $2 \%$ of Syrian SMEs are medium- 
sized, employing 20 to 250 people and the majority consists of micro-enterprises with Istanbul and Gaziantep being the leading locations. Syrian entrepreneurs in Turkey, therefore, fall into two categories. The first are big investors-namely, opportunity-seeking migrants who choose Istanbul not only due to refugee reasons but also for the profit opportunities that obtain there. Second are SMEs that reflect the classical approach of refugee entrepreneurship, which is driven by survival attributes and necessity (Wauters \& Lambrecht, 2008) rather than maximizing profits in new locations (Bizri, 2017). This article focuses on this latter category of small entrepreneurs.

The density of local communities, economies, and integration policies set the meso-level opportunities for Syrian entrepreneurs. Local community density is essential since most of the immigrant entrepreneurs provide culture-specific goods and services. The greater share of Syrians is registered in Istanbul $(546,296)$, followed by Gaziantep $(437,844)$ and Hatay $(427,500)$. They amount to $3.63 \%$ of the city population of Istanbul, $21.6 \%$ in Gaziantep, and $26.5 \%$ in Hatay (DGMM, 2019). Gaziantep and Hatay certainly have excellent market conditions for Syrian entrepreneurs, with their large immigrant populations. However, Istanbul-as the commercial centre of Turkey and home to 15 million residents-offers a large and vibrant market that serves over half a million Syrians, in addition to other Arabic-speaking tourists who demand a large variety of products. Despite the large Syrian population, no city-level integration policy has been implemented in Istanbul, although the Istanbul Chamber of Commerce has a specialist providing counselling for Syrian entrepreneurs. Some NGOs also run support initiatives. Nevertheless, it appears that no formal means to serve the potential immigrant and tourist market in Istanbul has yet been established. As observed by Uysal et al. (2018, p. 50), most of the Syrian entrepreneurs aim to cater to Syrian customers and have opened small shops-market stalls, restaurants, butcher shops, and bakeries-in neighbourhoods where the Syrian population concentrates.

Gaziantep and Hatay have denser Syrian populations concentrated in certain districts (Gültekin, 2018; Harunoğulları \& Cengiz, 2014) as well as local integration efforts. Their difference lies in the scale of economic opportunities. Turkey and Syria have long-standing historical and cultural relations intertwined with mixed marriages and cross-border trade partnerships, especially between Aleppo, on the Syrian side, and Gaziantep and Hatay on the Turkish side. Gaziantep was a famous trade city on the Silk Road, and still has a robust private sector and formal and informal cross-cultural, regional and international trade networks. Mutual economic relations have shifted, becoming more visible on Turkish territory after the mass refugee influx began in 2011. The Gaziantep municipality has supported and eased procedures for Syrians' opening manufacturing businesses in the locality-namely, in the organized industry district called GATEM. During the field research, Syrian en- trepreneurs were visible in the manufacturing, textile, catering and service sectors, as well as in trading.

Hatay provides a culturally welcoming context, with its established Arabic-speaking minority. Since 2015, projects have been carried out in cooperation with the United Nations, and local branches of Turkey's labour agency that support Syrian entrepreneurship and labour force participation. However, the economic scale of the city is relatively small, as is the available seed capital. Özkul and Dengiz's (2018) survey shows that marital status, professional and business experience, monthly income and years spent in Hatay are critical factors in Syrian entrepreneurship in the area. In this location, the majority of enterprises are in the range of 10,000 to 20,000 TL in start-up capital, employ between one and two people and provide goods mostly to the settled Syrian population.

\section{Methodology and Field Research}

Empirical data for this qualitative study came from field observations and 24 in-depth semi-structured interviews with Syrian small entrepreneurs conducted at their workplaces in three cities-namely Istanbul, Gaziantep, and Hatay, in 2018-2019. Eight interviews were conducted in each city. Interviewees were reached by directly approaching the shops in the districts populated by immigrants and tourists. Criteria for interviewees were to be Syrian entrepreneurs who had started in Turkey after 2011 and willingness to participate in the research. The author and two research assistants fluent in Arabic carried out the interviews. Additionally, the respective city Chambers of Commerce were visited in all three locations in order to gather information about their activities and reports on local Syrian entrepreneurs. The Hacettepe University Ethics Committee gave ethical approval to the study.

Interviewees were grocers, barbers, hairdressers, tailors, cell-phone sellers, owners of restaurants, shoe and textile shops, as well as a kindergarten owner, manufacturers and wholesalers, aged 25 to 50 . Five of them were university graduates and the others had between eight and nine years of formal education. Interviewees had urban backgrounds; three were from Latakia and two from Al-Hasakah, with all the others from Aleppo. They had been in Turkey for four to six years. Semi-structured interview questions were organized around themes of migration and entrepreneurship stories. The interview transcripts were repeatedly reviewed and the narratives analysed according to common turning points, foci, and diversities, and were coded and then thematized according to the conceptual framework as well as insights that arose from the specific narratives.

\section{Findings}

The findings are organized under four themes: (1) creating mobility and choosing localities; (2) coping with 
downward social mobility; (3) starting-up; and (4) sustaining the business. The discussion details, for each theme, how (i.e., by which strategies) interviewees utilized their various forms of capital.

\subsection{Creating Mobility and Choosing Localities}

Social capital facilitates both the spread and the concentration of migration (Faist, 2000). In the case of Syrian immigrants in Turkey, it accounts for their spread across cities as well as their concentration in certain districts. Kinship relations and the social-economic qualities of the cities were essential criteria for interviewees. In all three cities, interviewees were aware of solidarity among networks, used their connections to choose the destination, and settled near their connections:

We had to flee from Syria. We came here directly because we have relatives living here. [Before the war] we used to visit one another regularly. We are related to 30 families here in Gazikent. Some of them have Turkish citizenship. (A5, male, 40, machine moulder)

Long-standing kinship relations thus made Gaziantep and Hatay first destinations. This holds with results of field studies in Gaziantep where 79\% of participants declared having kinship relations in the area (Gültekin, 2018). Besides kinship relations, interviewees know Hatay as a border city and perceive it as culturally close to Syria:

I choose Hatay because there are lots of Turkmen people here. When I walk in the streets of Hatay, I feel as if I was in Lazkiye [his hometown]. People in Hatay speak Arabic. The people and culture are very much alike. I like to hear the Alevi accent. (H4, male, döner buffet owner)

Istanbul was the second settlement for all the interviewees. It was chosen for its economic opportunities. Interviewees used weaker ties, such as friends of friends, for finding jobs and lodging, which enabled their mobility. They first settled in other small cities, passed some time, gained knowledge and found new connections (or revitalized old ones) before making their way to Istanbul.

\subsection{Coping with Downward Social Mobility: Depreciation and Re-Accumulation of Forms of Capital}

As social capital is highly local (Faist, 2000), within the context of international migration, the value of institutionalized cultural capital may weaken or diminish in the host country. For example, fleeing migrants are not necessarily able to bring all the pertinent documentation with them. Convertibility to economic capital can also be undermined if the host country will not recognize diplomas or due to labour market restrictions on specific sectors, such as health and law. Uysal et al. $(2018, p .7)$ note that "one in five unemployed Syrians say that they cannot provide the necessary documents such as diplomas. One in five unemployed Syrians say that their relevant skills are not recognized." Eight of the interviewees were university graduates but none could work in their profession. Interviewee I3 was a male nurse in Syria; however, his diplomas were not valid in Turkey, and he eventually set up as a middleman:

I was a nurse in Syria. I had a good home and a good salary. I also had my trade. I came here and became a worker. I lost everything. I was affected by this change. It was very hard for me. I went to a psychologist, then in time I met new people and made new connections. Slowly, I started to do some small trades. Now I have a lot of social connections; I am a known person. I am a flexible trader, collecting orders and selling things made by Syrians here, such as dresses and buckles. (13, male, middleman)

Regardless of the level of education, all interviewees talked about losing their social status during the migratory process. They lost their jobs and left behind some of their economic capital (shops, real estate) as well as most of their social connections, trade partners, colleagues and kinship ties. This is a concrete example of devaluation of an agent's stock of various forms of capital in the process of irregular migration, as discussed in the following sections.

Our life was wonderful in Syria. I was trading in Antep pistachios and household and kitchen appliances. We had to leave everything behind and flee when the war started. I was unemployed for a time, and then I worked several daily jobs. It was hard. In time I found a Syrian partner, and we opened this shop. Now we are buying second-hand kitchen appliances to repair and then re-sell them. 95\% of our customers are Syrians; only poor Turks come to our shop (H7, male, craftsman).

Interviewees followed similar strategies for coping with downward social mobility. First, they admitted the situation, passed the emotional stage of dealing with feelings of loss, and worked various jobs to survive. They got to know new people, used the solidarity among kin and co-ethnics - in short, they reacquired social capital-and founded start-up businesses.

\subsection{Starting-Up}

\subsubsection{Finding the Money for Investment}

People with established economic capital in Syria were able to move some of it to Turkey. Others who did not possess enough economic capital for a start-up in Turkey worked and saved money and pooled resources and loans in the family for investment: 
My family and friends supported me. Without their support, I could not even buy myself a wheelbarrow. (H2, male, shoe shop owner)

This finding aligns with studies pointing out the importance of social networks among Syrian refugees (e.g., Refai et al., 2018; Shneikat \& Alrawadieh, 2019). In the case of Gaziantep, the survey carried out by Gültekin (2018) shows the strength of solidarity relations in the immigrant community, as $54 \%$ of participants declared that they could ask for a loan from kin and $34 \%$ from friends.

\subsubsection{Finding the Idea}

As mentioned above, although the institutionalized cultural capital lost its convertibility within Syrian-Turkish migration, Syrian entrepreneurs nevertheless utilize embodied cultural capital (Bourdieu, 1986) in four forms to find the idea for a new enterprise:

1. Entrepreneurship experience:

We were in food commerce in Damascus. I know how to do it. So, I took over this grocery here. (18, male, grocer)

2. Knowledge of occupations (such as tailor or shoemaker):

Shoemaking is the craft of Turkmens in Syria. We have been craftsmen for generations. It is our family business. So, I did what I know and opened this shoe factory. (A1, male, shoe atelier)

3. Manufacture know-how:

I was doing the same business in Aleppo, running a printing house and a carton packaging factory. It is a family tradition to work this way, starting with my grandfather. So, I started the same kind of business here. (A2, male, packaging manufacturer)

4. Cultural knowledge such as understanding groupspecific aesthetic preferences and tastes (especially in restaurants and with barbers) and language:

Syrian friends prefer [doing business with] us. Because we speak the same language, they can express themselves here, and I understand what they want. (16, male, barber)

Twenty-one of the interviewees were also entrepreneurs before the war, so they sought to continue their business in the new setting. Craftsmen utilized their professional skills for starting-up businesses. Know-how in the manufacturing of certain goods, such as shoemak- ing and machine moulding, was also utilized. Knowledge of aesthetic and group-specific preferences and tastes is vital for seizing market opportunities, utilized in the food and textile service sectors by restaurants, buffets, barbers, tailors, etc. It also enables them to meet the immigrant population's consumer demand. Embodied cultural capital affects ideas about what to do and how to do it, thus explaining the sectoral concentration of Syrian small entrepreneurs. When institutional cultural capital is lost when official recognition in the new setting is not forthcoming, embodied cultural capital becomes a survival asset. Profitability depends on unofficial/community-level recognition and demand for the produced goods and services.

\subsubsection{Meeting Consumer Demand: Utilizing Cultural, Social and Symbolic Capital}

Cultural, social and symbolic forms of capital are utilized to meet consumer demand in local immigrant hubsnamely, catering, hairdressing, and the grocery business. Entrepreneurs developed four strategies for re-acquiring social capital, depending on the particular production sector. The first strategy is to start where they aredense immigrant districts-and to leverage shared symbolic (Arabic language) and cultural capital (knowledge of tastes):

There was no one around selling groceries. So, I decided to open a grocery shop. People here need Syrian goods. (H3, male, grocer)

The second strategy, primarily used by manufacturers, is leveraging pre-migratory social capital-that is, the network of old customers - to found start-ups and promote transnational trade relations:

I have 15 years of experience in graphic design. When I was in Syria, I had customers from Bahrain to Qatar. I did not cut my ties with them after I came here. I am still working for them. I know what they like. After three years in Turkey, I still have no Turkish customers. I work for customers in 15 countries. Today, for example, I made a design for a restaurant in Germany. (A8, male, graphic designer)

The third strategy is to leverage symbolic capitaldrawing on the reputation earned in Syria, such as old and known firm names-when opening a new business in Turkey.

We had a school in Aleppo. I used the same name [her family name] for this new kindergarten [in Turkey]. It was quite well-known in Aleppo. And yes, [the name recognition] was very useful. When people see it, they trust us and send their children to us. In the education sector, trust is a must. (A4, female, kindergarten owner) 
The fourth strategy-used by middlemen, wholesalers and traders-is to connect Syrian producers and customers in various localities. There are trade chainsa manufacturer in Gaziantep produces, say, canned Syrian food, which wholesale traders then transport to Istanbul's Rami passage in the Fatih district, and grocers buy from there and on-sell to Syrians in various districts of Istanbul:

Here I sell Syrian food: salami, cheese, spices. Syrians come and buy from me. There is a factory in Antep that produces Syrian food in Turkey. I source from there. There is a wholesaler's bazaar in Fatih, called Rami. Everyone knows it. I buy products from there also. (17, male, grocer)

Some interviewees were able to reconnect to their old customer networks; others established new relations with immigrant communities; others still market to local citizens. All of this adds up to a re-accumulation of social capital via cultural and symbolic capital.

\subsubsection{Re-Accumulating Social and Cultural Capital to Reclaim One's Place}

Re-accumulating social capital and revalidating the cultural capital necessary for a start-up requires time, especially when people have relatively little economic capital. The first strategy is to work for other people in the sector, make connections and learn ways of doing business in their localities and then open shops. Two women hairdressers and three barbers interviewed first worked at other hairdressers and then, after gaining some experience, started their own shops:

I know entrepreneurship. I wanted to continue what I know. But in the beginning, I had difficulties. I did not know where to buy the products. In Syria, no matter where you go, the same things have the same price. But it is not like that in Turkey. I had difficulties in finding where to buy quality products at reasonable prices. I asked around. Turkish friends helped me a lot in this. They directed me to people in Istanbul instead of Antep. (H5, shoe and clothing retailer)

The second strategy is to build a dialogue with Turkish colleagues. Re-acquiring social capital is crucial for developing knowledge about how the local market works, about where to acquire the needed goods. Turkish friends are useful for acquiring knowledge about opening businesses and legal regulations:

Both Turks and Syrians were helpful. I am a stranger and lacked the necessary information to trade in Turkey. I learned this from new contacts. Turkish friends informed and helped me with the legal procedures to open a business. (A1, male, shoe atelier)
The third strategy-a quick way to achieve legal knowledge-is to attend training programs or projects NGOs run on developing local entrepreneurship:

The Danish Refugee Council has opened an entrepreneurship course here. They teach us everything we need in four months-all the details, legal requirements, and how to meet them. Licensing, social security...[and] what to do if someone cheats you, etc. It was beneficial. They gave us money and food during the course. ( $\mathrm{H} 2$, male, shoe retailer)

The initial strategies of starting as an employee and investing in social capital by making Turkish friends and gaining knowledge about local markets are individual strategies and require time. However, the third strategy-gaining knowledge and sometimes seed capital via attending projects-depends on meso-level relations, the actions of local government, and civil society. This strategy requires less time and suggests that local integration projects have the potential to hasten start-up formation and the formalization of immigrant entrepreneurship, thus supporting integration. Whether the enterprise is formal or informal affects its sustainability, as well as the owner's integration.

\subsection{Sustaining the Business: Strategies and Challenges}

The type and sector of entrepreneurship and the strategies for sustainability depend not only on an agent's ability to utilize forms of capital but also on the strategies of other agents and the social milieu. Rival entrepreneurs are also agents with tactics and strategies; hence, there are counter-strategies for sustainability in the market. The local economy is a game field full of trade relations and trust as well as cheating and injustice. Being in the informal sector makes this field more complicated and riskier, offering advantages as well as competition. The first strategy is to remain secluded, accept informality and keep prices low:

The first challenge is choosing a place for business. It should not be near a Turkish shop. For example, there are many Syrians in our neighbourhood; hence, you should open a shop that appeals to Syrians not one that Turks are running or that appeals to the Turks. Second, especially now, if you want to start up, in order to avoid problems, you should register and get a licence.....Now l've been running this place for four years. I have had no problems because I'm a bit far from the centre, far from the region of the Turks. This is important because, for example, they [Turks] cannot compete with us on price, and they have to register and pay tax. For example, I sell a phone-charger for 30 TL which they cannot sell below 50 TL. We don't have tax. So, stay clear of business near the Turks. (H1, cell-phone seller) 
Being in the informal market relieves entrepreneurs from paying tax and the costs of social security and helps retailers keep prices low, which results in price differences between formal and informal markets and hence paves the way for negative attitudes and envy between local and immigrant entrepreneurs:

Now for the traders, they are jealous when we open. I'm selling cheaper; customers love me. For example, I have two Turkish friends; they cooperate. I also want to buy and sell Turkish goods, but nobody sells them to me. I want to sell Turkish cheese and sausage, yoghurt, eggs, and chips but the wholesalers don't sell to me. I can only sell Syrian goods. For two years, I've been trying to buy a locker to sell ice-cream, but nobody will sell me one. I can't get over it. I have no solution. I don't want to have enemies around, so I have to shut up. For example, in the grocery store next door, there are both vegetables and fruits, and ice-cream. I have money, I could get into this business, but I do not want to attract hostility, so I steer clear [of this market]. (I2, male, grocer)

Here, the strategy for sustainability in the face of exclusion tactics is not to expand the business but to keep it small, which decreases employment and integration potential. Syrian entrepreneurs generally work with Syrian workers, as a typical example of refugee entrepreneurship (Bizri, 2017) and ethnic economies (Katila \& Wahlbeck, 2012). The immigrant co-ethnic population provides a hub of workers who know the work, are easy to communicate with and are docile. In Istanbul and Hatay, all the interviewees were either selfemployed or employers of two to three people and unregistered. Working conditions in the sector are hard. All seven self-employed were working on average 12 hours per day. However, working conditions improve as the size of the enterprise grows, as observed in Gaziantep. Gaziantep's strategy to support manufacturers helps Syrian entrepreneurs become stronger and provide more employment as the business grows; they tend to pay social security at least for some long-standing and essential employees:

I have fifty, sixty workers. Eight to ten of them are Turkish, and the rest are Syrians. We have two shifts; they work eight hours each. They work for minimum wage. But master shoemakers sometimes earn up to 4,000 TL a month....My accountant takes care of this. I have ten insured workers. I pay the insurance for those who have been working with me for a long time and are most useful. (A2, male, shoe atelier)

Meso-level opportunity structures (Kloosterman, 2010) and local governmental integration policies may help entrepreneurs to formalize and grow their businesses, and provide jobs both for immigrants and locals, which paves the way for economic and social integration.

\section{Discussion: Utilization of Immigrant Capital and Integration}

To recap, the concept of social capital proves useful in understanding refugee entrepreneurship. Bourdieu's (1986) concept of forms of capital-economic, social, cultural and symbolic-thus form the base of the analysis, as well as Kloosterman's (2010) formulation of opportunity structure. Findings show that in addition to connecting entrepreneurs and co-ethnic labour (Bizri, 2017; Katila \& Wahlbeck, 2012), social capital also explains the scattering of Syrians and their small business in Turkey. Cultural capital, especially in its embodied form, explains the sectoral concentration of Syrian small entrepreneurs.

Further, the study indicates that restrictions on the convertibility of institutionalized cultural capital via restrictions of the validity of diplomas and labour force participation or language barriers compose a macro-level structure diminishing the value of refugees' capital, restricting their agency, and disadvantaging them in the market. Some refugees partly surmount this situation via utilizing their embodied cultural capital, such as entrepreneurial experience, know-how of a certain production method, as well as knowledge of Syrian culture and Arabic. The profitability of this strategy depends on the local meso-level opportunity structure, especially the existence of co-ethnic groups and cultural similarities with the host country. Hence, Gaziantep and Hatay have witnessed a growing number of Syrian enterprises, both formal and informal, despite the fact that their economies are smaller than cities like Ankara, Izmir or Antalya. Utilization of embodied cultural capital also explains why most Syrian entrepreneurs start up in co-ethnic districts and sell culturally specific products, as noted by Uysal et al. (2018) and Harunoğulları and Cengiz (2014).

Beyond focusing on personal motivations (Mawson \& Kasem, 2019; Obschonka \& Hahn, 2018), analysing the utilization of forms of capital helps us to think about individual entrepreneurs in relation to their social environment and to the accumulation of relations of labour in time, concerning their personal positions within the old and new social and economic contexts. Forms of capital can be converted, depending on the situation (Bourdieu, 1986). The findings show that the vitality of transferring, re-acquiring and converting capitals changes according to the interviewees' type of business. First, for the producers of direct goods and services, such as restaurants and barbers, re-acquiring social capital through establishing relations with local people and the immigrant community allowed local demand to be met. They mainly utilize their knowledge of aesthetic preferences. For finding seed capital, most of them worked in other jobs and utilized resources and loans from family and kin. Second, for the producers of intermediate goods, such as carton packaging or the machine moulding business, reacquiring social capital in the new location among trade networks and utilizing social capital for trustworthy relations with other business people was important; exper- 
tise of local knowledge was crucial, and transfer of knowhow was not a problem. Third, for the traders-such as retailers, grocery owners and middlemen connecting producers-re-acquiring social capital both to reach daily customers and wholesale networks and leveraging symbolic capital, such as respect and trust within the small business environment, were the main strategies. Studies on refugee entrepreneurship generally concentrate on single case studies (Bizri, 2017) or entrepreneurs in one sector like catering (Wahlbeck, 2007) or hospitality (Shneikat \& Alrawadieh, 2019). This finding indicates that cross-sector comparative studies are one avenue for future research.

This study also shows that a host country with a wide informal sector not only channels immigrant labour to informal jobs but also expands the chances of informal start-ups (Özar, 2016). An original finding is that being in the informal sector affects refugee entrepreneurs' strategies for sustaining the business, bringing about distortions and unpredictability in integration, a relatively under-researched topic in the literature.

\section{Conclusion: Refugee Entrepreneurship and Integration in the Shadow of the Informal Economy}

Immigrant entrepreneurship has been on the scholarly agenda for a long time (Borjas, 1986), whereas refugee entrepreneurship studies are relatively new. Studies (Meister \& Mauer, 2019; Shneikat \& Alrawadieh, 2019) underline that as refugees start and manage their own businesses, they simultaneously become embedded in the host economy and society. Refugee entrepreneurship has been suggested as a tool for integration (Bizri, 2017; Refai et al., 2018; Shneikat \& Alrawadieh, 2019). The discussion on integration has focused largely on economic integration, participation in the labour force and language proficiency. The integration literature is generally concentrated on European countries where informal economic relations are relatively scarce compared to the Middle Eastern economies. The Turkish examplewith its comparatively wide informal economy embracing both nationals and immigrants-is a salient case to introduce the impact of the informal economy into the integration discussion. In this article, integration was conceptualized in this study as an interaction between macro- and meso-level structures and the microstrategies of agents.

The findings of this study have implications for the two realms of integration-namely, relations with the state and with the market. Syrian entrepreneurship is highly affected by its relations with the stateregistration and settlement policy as well as labour market regulations. Late registration and the existing migration governance strategy of prohibitions without control, the lack of effective oversight of commercial workshops despite regulations, strict, top-down settlement policy, and restrictions on mobility all open up a new grey zone for informal economic relations for irregular migrants.
The slippery ground of the informal economy limits the agency of Syrians under temporary protection in their relations with the state. While the informal economy eases setting up a new shop (no bureaucracy, just verbal contracts) it also implies: (1) no legal grounds for defending oneself in the market; (2) not being entirely accepted by the trade; and (3) defensive strategies that keep the enterprises small.

Refugee entrepreneurship is seen as a tool for enhancing economic and social integration. But in the Turkish case, one needs to underline the differentiation between formal and informal immigrant entrepreneurs. Hence relations with the state and the market are interconnected realms of integration. Informal entrepreneurship does not seem effective in enhancing integration in terms of relations with the state. It provides informal jobs and some money for the daily survival of immigrant workers. Such businesses tend to remain small, hence having a limited effect on economic and social integration.

Being in the informal sector keeps the business small and also reinforces concentration in immigrant districts, in addition to the initial effects of social capital that concentrates immigrant settlement in certain localities. It limits entrepreneurship's effects on the relations between Syrians and Turkish people in two ways. First, it limits production and trade by Syrian entrepreneurs that could create an atmosphere of exchange between the two cultures. Second, and relatedly, it limits the potential acts of exchange, dialogue, and daily encountersin short, relations with the host community. The insecurities arising from informality lead to precariousness in connecting with the host community, and thus isolation. None of the interviewees in the present study reported connections with civil society organizations, which are generally understood to be social aid providers.

Despite these limitations, small Syrian entrepreneurship is undoubtedly a tool for survival that has the potential for further development. Some entrepreneurs even have international trade relations, which harbours the potential for enhancing transnational relations. Differences in cities' meso-level opportunity structures indicate that local integration policies provide an opportunity to formalize existing small enterprises, which may open new channels for integration as well as increasing production and employment.

\section{Conflict of Interests}

The author declares no conflict of interests.

\section{References}

Alexandre, L., Salloum, C., \& Alalam, A. (2019). An investigation of migrant entrepreneurs: The case of Syrian refugees in Lebanon. International Journal of Entrepreneurial Behavior \& Research, 25(5), 1147-1164.

Baban, F., Ilcan, S., \& Rygiel, K. (2017). Syrian refugees in 
Turkey: Pathways to precarity, differential inclusion, and negotiated citizenship rights. Journal of Ethnic and Migration Studies, 43(1), 41-57.

Bizri, R. M. (2017). Refugee-entrepreneurship: A social capital perspective. Entrepreneurship and Regional Development, 29(9/10), 847-868.

Borjas, G. (1986). The self-employment experience of immigrants. Journal of Human Resources, 21(4), 485-506.

Bourdieu, P. (1986). The forms of capital. In J. Richardson (Ed.), Handbook of theory and research for the sociology of education (pp. 241-258). New York, NY: Greenwood.

Bourdieu, P. (2013). Symbolic capital and social classes. Journal of Classical Sociology, 13(2), 292-302.

Building Markets. (2018). One year later: Revisiting the contributions of Syrian entrepreneurs in Turkey. New York, NY: Building Markets. Retrieved from https://buildingmarkets.org/sites/default/files/ pdm_reports/bm_syrian_sme_update_one_year_ later_final_2_072518.pdf

Carree, M., Congregado, E., Golpe, A., \& van Stel, A. (2015). Self-employment and job generation in metropolitan areas, 1969-2009. Entrepreneurship \& Regional Development, 27(3/4), 181-201.

Ceritoğlu, E., Yunculer, H., Torn, H., \& Tumen, S. (2017). The impact of Syrian refugees on natives' labor market outcomes in Turkey. IZA Journal of Labor Policy, 6(1), 1-28.

Elgin, C., \& Sezgin, M. B. (2017). Sectoral estimates of informality: A new method and application for the Turkish economy. The Developing Economies, 55(4), 261-289.

Faist, T. (2000). Volume and dynamics of international migration and transnational social spaces. Oxford: Oxford University Press.

General Directorate of Migration Management. (2019). Statistics. DGMM. Retrieved from https://www.goc. gov.tr/icerik3/gecici-koruma_363_378_4713

Gültekin, M. N. (2018). The social solidarity and interaction points of the Syrian refugees in Gaziantep. Turkish Studies, 13(26), 673-692.

Güven, S., Kenanoğlu, M., Kadkoy, O., \& Kurt, T. (2018). Syrian entrepreneurship and refugee start-ups in Turkey: Leveraging the Turkish experience 2018. Ankara: TEPAV.

Harunoğulları, M., \& Cengiz, D. (2014). Suriyeli göçmenlerin mekânsal analizi: Hatay (Antakya) örneği [Spatial analysis of Syrian immigrants: Case of Hatay (Antakya) English]. In E. Yılmaz (Ed.), Proceedings of TÜCAUM VIII: Geography Symposium (pp. 309-318). Ankara: Ankara University.

ICG. (2018). Turkey's Syrian refugees: Defusing metropolitan tensions. International Crisis Group. Retrieved from https://www.crisisgroup.org/europe-centralasia/western-europemediterranean/turkey/248turkeys-syrian-refugees-defusing-metropolitantensions
Katila, S., \& Wahlbeck, Ö. (2012). The role of (transnational) social capital in the start-up processes of immigrant businesses: The case of Chinese and Turkish restaurant businesses in Finland. International Small Business Journal, 30(3), 294-309.

Kızılay. (2019). April 2019 report. Ankara: Kızılay. Retrieved from https://www.kizilay.org.tr/Upload/ Dokuman/Dosya/nisan-2019-suriye-krizi-insaniyardim-operasyonu-raporu-24-05-201991149829.pdf

Kloosterman, R. C. (2010). Matching opportunities with resource: A framework for analyzing (migrant) entrepreneurship from a mixed embeddedness perspective. Entrepreneurship and Regional Development, 22(1), 25-45.

Kutlu, M. (2019). Türkiye'deki Suriyeli mültecilerin işgücü piyasasına ve istihdama etkileri: Gaziantep, Adıyaman, Kilis örneği [An evaluation on the impact of the Syrian refugees in Turkey on labor market and employment: Example of Gazgiantep- Adıyaman-Kilis]. Dicle University Journal of Economics and Administrative Sciences, 9(7), 45-59.

Lordoğlu, K., \& Aslan, M. (2016). En fazla Suriyeli göçmen alan beş kentin emek piyasalarında değişimi 2011-2014 [Change of labour markets of the 5 cities which allow migrants at most: 2011-2014]. Çalışma ve Toplum Dergisi, 49(2), 789-808.

Mawson, S., \& Kasem, L. (2019). Exploring the entrepreneurial intentions of Syrian refugees in the UK. International Journal of Entrepreneurial Behavior \& Research, 25(5), 1128-1146.

Meister, A. D., \& Mauer, R. (2019). Understanding refugee entrepreneurship incubation: An embeddedness perspective. International Journal of Entrepreneurial Behavior \& Research, 25(5), 1065-1092.

Ministry of Family, Labour and Social Services. (2019). Labour statistics 2017. Ankara: Ministry of Family, Labour and Social Services. Retrieved from https://www.ailevecalisma.gov.tr/media/3372/ yabanciizin2017.pdf

Mutlu, M., Mısırlı, K. Y., Kahveci, M., Akyol, A. E., Gümüşcan, E. E., Pınar, İ., \& Salman, C. (2018). The integration of Syrian immigrants to Istanbul's textile sector. Çalışma ve Toplum, 56(1), 69-92.

Obschonka, M., \& Hahn, E. (2018). Personal agency in newly arrived refugees: The role of personality, entrepreneurial cognitions and intentions, and career adaptability. Journal of Vocational Behavior, 105, 173-184.

OECD. (2008). Declaring work or staying underground: Informal employment in seven OECD countries. Paris: OECD. Retrieved from https://www.oecd.org/ employment/emp/40843646.pdf

Özar, Ş. (2016). Women entrepreneurs in Turkey: Obstacles, potentials, and prospects. In M. Karshenas, V. M. Moghadam, \& N. Chamlou (Eds), Women, work and welfare in the Middle East and North Africa (pp. 
235-262). London: Imperial Collage Press.

Özkul, G., \& Dengiz, S. (2018). Economic contributions of Syrian immigrants to the Hatay province in the context of immigrant entrepreneurship. Mehmet Akif Ersoy University Journal of Social Sciences Institute, 10(26), 897-919.

Palacıoğlu, T. (2019). Suriyeli sığınmacılar ve istanbul'daki girişimleri. Istanbul: Istanbul Chamber of Commerce.

Refai, D., Haloub, R., \& Lever, J. (2018). Contextualizing entrepreneurial identity among Syrian refugees in Jordan: The emergence of a destabilized habitus? The International Journal of Entrepreneurship and Innovation, 19(4), 250-260.

Shneikat, B., \& Alrawadieh, Z. (2019). Unravelling refugee entrepreneurship and its role in integration: Empir- ical evidence from the hospitality industry. The Service Industries Journal, 39(9/10), 741-761.

TÜik. (2019). Labour force statistics March 2019. Turkish Statistical Institution. Retrieved from http://www. tuik.gov.tr/PreHaberBultenleri.do?id=30683

Uysal, G., Gursel, S., Anil, B., Uncu, B. A., \& Bakis, O. (2018). Opportunities for Syrian youth in Istanbul: A labor market assessment. Istanbul: International Youth Foundation.

Wahlbeck, Ö. (2007). Work in the kebab economy: A study of the ethnic economy of Turkish immigrants in Finland. Ethnicities, 7(4), 543-563.

Wauters, B., \& Lambrecht, J. (2008). Barriers to refugee entrepreneurship in Belgium: Towards an explanatory model. Journal of Ethnic and Migration Studies, 34(6), 895-915.

\section{About the Author}

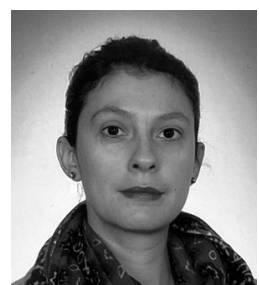

Reyhan Atasü-Topcuoğlu is an Associate Professor at Hacettepe University, Department of Social Work, Ankara, Turkey. She holds a PhD in Sociology from Humboldt University of Berlin. Her research interests include migration, refugees, human trafficking, social policy, welfare states, human rights, and feminist theory. She is the author of Ideology and Human Trafficking published by Routledge and also several other articles. 